Revista de Metalurgia 52(3)

July-September 2016, e076

ISSN-L: 0034-8570

doi: http://dx.doi.org/10.3989/revmetalm.076

\title{
Sorption of ferrous iron by EPS from the acidophilic bacterium Acidiphilium Sp.: A mechanism proposal
}

\author{
Jaime M. Tapia ${ }^{\mathrm{a}, \bigotimes}$, Jesús Muñoz ${ }^{\mathrm{b}}$, Felisa González ${ }^{\mathrm{b}}$, María L. Blázquez ${ }^{\mathrm{b}}$, Antonio Ballester ${ }^{\mathrm{b}}$ \\ ${ }^{a}$ Universidad Arturo Prat, Facultad de Ingeniería y Arquitectura, Laboratorio de Procesos Acuosos, \\ Cl. Arturo Prat Chacón 2120, Iquique, Chile \\ ${ }^{b}$ Universidad Complutense, Departamento de Ciencia de los Materiales e Ingeniería Metalúrgica, \\ Av. Complutense s/n, 28040 Madrid, Spain \\ ${ }^{\square}$ Corresponding author: jtapia@unap.cl
}

Submitted: 27 October 2015; Accepted: 22 May 2016; Available On-line: 14 October 2016

\begin{abstract}
The aim of this work was to assess the uptake of Fe(II) by extracellular polymeric substances (EPS) from the acidophilic bacterium Acidiphillium 3.2Sup (5). These EPS were extracted using EDTA. EPS of $A$. 3.2Sup (5) loaded in sorption tests with $\mathrm{Fe}(\mathrm{II})$, were characterized using the following experimental techniques: scanning electron microscopy (SEM) with energy dispersive X-ray microanalysis (EDX), X-ray diffraction (XRD) and Fourier transform infrared spectroscopy (FTIR). The experimental results indicate that EPS adsorb ferrous iron according to Freundlich model with a metal sorption uptake of $K=1.14 \mathrm{mg}^{1-1 / \mathrm{n}} \mathrm{L}^{1 / \mathrm{n}} \mathrm{g}^{-1}$ and a sorption intensity of $1 / n=1.26$. In addition, ferrous iron sorption by EPS took place by preferential interaction with the carboxyl group which promotes the formation of ferrous iron oxalates $\left(\mathrm{FeC}_{2} \mathrm{O}_{4}\right)$. Since the interaction reaction was reversible $(\log K=0.77 \pm 0.33)$, that means that the cation sorption can be reversed at convenience.
\end{abstract}

KEYWORDS: Acidiphilium; Bacterium; EPS; Ferrous iron; Oxalate; Sorption

Citation / Cómo citar este artículo: Tapia, J.M., Muñoz, J., González, F., Blázquez, M.L., Ballester, A. (2016) "Sorption of ferrous iron by EPS from the acidophilic bacterium Acidiphilium Sp.: A mechanism proposal”. Rev. Metal. 52 (3): e076. doi: http://dx.doi.org/10.3989/revmetalm.076

RESUMEN: Mecanismo de biosorción de hierro ferroso por sustancias poliméricas extracelulares de la bacteria acidófila Acidiphilium sp. El objetivo de este trabajo fue estudiar la absorción de Fe(II) por Sustancias Poliméricas Extracelulares (SPE) provenientes de la bacteria acidófila Acidiphilium 3.2Sup (5). Las SPE fueron extraídas usando EDTA. SPE de A. 3.2Sup (5) cargadas con Fe(II) fueron caracterizadas usando las siguientes técnicas experimentales: microscopia electrónica de barrido (MEB) con microanálisis de energía dispersiva de rayos X (EDX), difracción de rayos X (DRX), y espectroscopía infrarojo (IR) con transformada de Fourier (EIRTF). Los resultados muestran que las SPE absorben Fe(II) según el modelo de Freundlich con un coeficiente de sorción $\mathrm{K}=1,14 \mathrm{mg}^{1-1 / \mathrm{n}} \mathrm{g}^{-1}$ e intensidad $1 / \mathrm{n}=1$,26. La captación de $\mathrm{Fe}(\mathrm{II})$ por las $\mathrm{SPE}$ ocurre a través de la formación de oxalatos de hierro $\left(\mathrm{FeC}_{2} \mathrm{O}_{4}\right)$, a través de una reacción reversible ( $\left.\log \mathrm{K}=0,77 \pm 0,33\right)$, lo cual implica que el hierro captado podría recuperarse si fuera de interés.

PALABARAS CLAVE: Acidiphilium; Bacteria; EPS; Hierro ferroso; Oxalato; Sorción

Copyright: (C) 2016 CSIC. This is an open-access article distributed under the terms of the Creative Commons Attribution License (CC-by) Spain 3.0. 


\section{INTRODUCTION}

There have been reports of the existence of microorganisms in the ecosystem of Rio Tinto (Huelva, Spain) which can accomplish the degradation of organic substrates with the simultaneous production of electrical energy under aerobic conditions (Malki et al., 2006). Among these microorganisms, bacteria of the genus Acidiphilium and Acidithiobacillus can establish a closed cycle in which the first bacterium can degrade aerobically organic compounds into $\mathrm{CO}_{2}$ and $\mathrm{H}_{2} \mathrm{O}$ using $\mathrm{Fe}$ (III) as terminal electron acceptor, while the second bacterium can oxidize again the reduced iron produced in the process.

In this way, Malki et al. has demonstrated the ability of bacteria Acidiphilium 3.2Sup (5) to transfer electrons to carbon electrodes in the presence of oxygen and without any electron mediator, producing an electrical current around $3 \mathrm{~A} \mathrm{~m}^{-2}$ at $+0.15 \mathrm{~V}$ SCE (Malki et al., 2008). On the other hand, cells of $A$. ferrooxidans were able to grow using $\mathrm{Fe}(\mathrm{II})$ as the sole energy source, generating thus Fe(III). Both facts indicate these microorganisms may be used in a microbial fuel cell (MFC) device to generate an electrical current as far as organic substrates and iron salts are provided to the system (Dopson et al., 2015).

An inherent process to the growth of different microbial consortia is the generation of extracellular polymeric substances (EPS). These substances are metabolic products exuded by cells which essentially consist of high molecular weight substances, such as: carbohydrates, proteins, humic substances, and nucleic acids, among others (Wingender et al., 1999).

Depending on its composition and acidity, the active functional groups of these exosubstances could play an important role in the uptake of metals, especially iron (Sand and Gehrke, 2006; Tapia et al., 2011). Since the formation of such substances is practically unavoidable, it is relevant to study the length and, specially, the mechanism of how these exosubstances (produced by pure microbial cultures of A. 3.2Sup (5)), absorb ferrous iron. Know the mechanism is important because can foresee the potential recuperation of iron adsorbed by EPS, if it is convenience.

A. 3.2Sup (5) has $99 \%$ genetic similarity with other microbial species such as A. cryptum, A. multivorum and $A$. organovorum (Malki et al., 2008) and its growth kinetics was significantly faster than A. ferrooxidans, averaging between 6 and 8 times more biomass (Tapia et al., 2011). On this basis, the interaction of iron in solution would take place preferentially with EPS produced by bacteria A. 3.2Sup (5). Moreover, since these bacteria are grown in a free-iron medium, the exosubstances produced by them do not contain the element, which leads to a more realistic EPS-Fe interaction (Tapia et al., 2011; Malki et al., 2013).
A difficult task in the analysis of EPS is related to its extraction from microbial consortia. There is no standard extraction method for EPS, but a wide variety of methods based on physical or chemical principles, or a combination of both. In this study, the extraction procedure of EPS cells has been described in a previous work which consisted of the addition of EDTA to pure cultures of $A .3 .2 \operatorname{Sup}(5)$ (Tapia et al., 2009).

The previous studies have shown sorption of $\mathrm{Fe}(\mathrm{III})$ (Tapia et al., 2011) and of $\mathrm{Fe}(\mathrm{II})$ and $\mathrm{Fe}(\mathrm{III})$ by EPS of A. 3.2Sup(5) (Tapia et al., 2013). Both of them studies were realized in aerobic conditions whereas in this paper the sorption of ferrous iron by these EPS, in anaerobic conditions in order to avoid the environmental oxidation of cation, was studied.

The sorption isotherms of $\mathrm{Fe}(\mathrm{II})$ by EPS of A. 3.2Sup (5) were obtained and then these exosubstances with bound ferrous iron were characterized by scanning electron microscopy (SEM) and by energy dispersive X-ray (EDX) microanalysis. Fourier Transform Infrared Spectroscopy (FTIR) and X-Ray Diffraction (XRD) techniques were used to model the interaction between the exosubstances and ferrous ion.

\section{MATERIALS AND METHODS}

\subsection{Bacterial Growth and EPS Extraction}

The strain of pure bacterium A. 3.2Sup (5), provided by Dr. R. Amils of the Molecular Biology Centre (CBM-CSIC, Spain), was accomplished aerobically in a liquid medium at $\mathrm{pH} 2.5$ and $30^{\circ} \mathrm{C}$ and stirred at $150 \mathrm{rpm}$. The nutrient medium used was similar to that employed during the isolation and characterization of the strain (per litre): $2.0 \mathrm{~g}$ $\left(\mathrm{NH}_{4}\right)_{2} \mathrm{SO}_{4}, 0.1 \mathrm{~g} \mathrm{KCl}, 0.25 \mathrm{~g} \mathrm{MgSO}_{4} * 7 \mathrm{H}_{2} \mathrm{O}, 0.25 \mathrm{~g}$ $\mathrm{K}_{2} \mathrm{HPO}_{4}, 0.01 \mathrm{~g} \mathrm{Ca}\left(\mathrm{NO}_{3}\right)_{2} * 4 \mathrm{H}_{2} 0,0.1 \mathrm{~g}$ of yeast extract and $1.0 \mathrm{~g}$ of glucose (Tapia et al., 2009) (all chemical reagents used were of analytical grade, PA). The cell density was obtained by cell counting using a hemocytometer and optical microscope.

Likewise, the EPS extraction method have been described previously (Tapia et al., 2009). The procedure used was: $40 \mathrm{ml}$ of pure strain was mixed (without stirring) with a solution of $2 \%(\mathrm{w} / \mathrm{v})$ EDTA disodium salt, using a ratio of $3.2 \mathrm{~g}$ of EDTA per gram of cell dry weight. After $3 \mathrm{~h}$ of contact at $4{ }^{\circ} \mathrm{C}$, the solution was centrifuged at $14.000 \mathrm{rpm}(20.817 \mathrm{~g})$ for $20 \mathrm{~min}$. Then, bacterial cells were separated from the supernatant through a $0.22 \mu \mathrm{m}$ millipore filter. The filtering, containing the raw EPS, was then dialyzed in order to remove metabolites and salts of low molecular weight using a membrane of 3500 daltons of molecular weight cut-off (MWCO) in $1.0 \mathrm{~L}$ of deionized water, for $24 \mathrm{~h}$ and at $4{ }^{\circ} \mathrm{C}$. The fine EPS solution was finally stored at $4{ }^{\circ} \mathrm{C}$ for chemical analysis. 


\subsection{EPS-Fe(II) Interaction}

The sorption tests were performed under strict anaerobiosis in order to avoid the environmental oxidation of ferrous ion. These tests were carried out mixing aliquots of EPS $(10 \mathrm{~mL}$ at an concentration of $0.83 \mathrm{mg} \mathrm{ml}^{-1} \mathrm{EPS}$ ) with aqueous solutions of $\mathrm{Fe}$ (II) at initial concentrations of 200, 1000 and $2000 \mathrm{mg} \mathrm{L}^{-1}$. Ferrous iron was added from a stock solution of hydratd ferrous sulphate, $\mathrm{Fe}\left(\mathrm{SO}_{4}\right) * 7 \mathrm{H}_{2} \mathrm{O}$ (99.9\%, Panreac), which was prepared in anaerobic atmosphere, at $4.0 \mathrm{~g} \mathrm{~L}^{-1}$, and adjusted at $\mathrm{pH} 2.0$ with $\mathrm{H}_{2} \mathrm{SO}_{4} 50 \%$ (v/v). All aqueous solutions were previously deoxygenated by using a gaseous mixture of $\mathrm{N}_{2} / \mathrm{CO}_{2}(80 / 20 \%$, Air Liquide).

The anaerobic conditions in the sorption tests were achieved by continuous circulation of the flow of $\mathrm{N}_{2} / \mathrm{CO}_{2}$ into the beakers utilized for these tests. The interaction tests lasted for $1 \mathrm{~h}$ to assure the saturation of EPS with Fe. This period of time was established as sufficient to reach equilibrium in a previous sorption study (Tapia et al., 2011). Then, the mixture of EPS with Fe(II) was placed on a dialysis cassette of $3500 \mathrm{MWCO}$, using a volume ratio of 50:1 (volume of deionized water to EPS loaded with ferrous cation). Dialysis was carried out under anaerobic conditions with stirring at $180 \mathrm{rpm}$ and at $4{ }^{\circ} \mathrm{C}$ for $24 \mathrm{~h}$.

Iron was measured in both of the samples of EPS loaded with metal, and in the dialysis water by atomic absorption spectroscopy (AAS) using a Perkin-Elmer model 1100B spectrophotometer. The ratio between the total iron measured in both samples and the initial iron available was very close at $100 \%$ (standard deviation: $\pm 3.9 \%$ ).

\subsection{Scanning Electron Microscopy (SEM) and Energy Dispersive X-ray Microanalysis (EDX)}

Samples of pure EPS and EPS loaded with ferrous iron were lyophilized at $-56^{\circ} \mathrm{C}$ and $1.2 \times 10^{6} \mathrm{Torr}$ for $48 \mathrm{~h}$ from known volumes of substances. The samples of EPS containing Fe(II) were produced in a test with an initial concentration of $1,000 \mathrm{mg} \mathrm{L}^{-1}$ of $\mathrm{Fe}(\mathrm{II})$, and a reaction time of $1 \mathrm{~h}$. A sample of freeze-dried EPS - loaded with Fe(II) - was coated with a conductive layer of gold and then analyzed using a scanning electron microscope (JEOL JSM6400 ) at an accelerating voltage of $20 \mathrm{kV}$, coupled with an energy dispersive X-ray microanalysis.

\subsection{Fourier Transform Infrared Spectrometry (FTIR)}

Two milligrams of freeze-dried EPS loaded with $\mathrm{Fe}(\mathrm{II})$ solution $\left(24 \mathrm{~h}\right.$ at $-56{ }^{\circ} \mathrm{C}$, Labconco SciLab) was mixed with $300 \mathrm{mg}$ of $\mathrm{KBr}$ and compacted into a pellet. IR spectra were obtained using a spectrum Nicolet Magna 750, at $4 \mathrm{~cm}^{-1}$ of resolution.

\subsection{X-Ray Diffraction (XRD)}

The freeze-dried EPS were ground in an agate mortar and then homogenized before analysis in a Philips X'pert-MPD diffractometer using a $\mathrm{Cu}$ anode was used. All measurements were performed with $\mathrm{Cu}-\mathrm{K} \alpha$ radiation at $1.5406 \AA$ wavelength and the $2 \theta$ angle was scanned between $5^{\circ}$ and $85^{\circ}$ for $1 \mathrm{~h}$.

\section{RESULTS AND DISCUSSION}

\subsection{Bacterial Growth and Composition of EPS}

The maximum bacterial density of cultures of A. 3.2Sup (5) at $216 \mathrm{~h}$, stage of maximum growth, was $1.14 \times 10^{9}$ cells $\mathrm{ml}^{-1}$. This shows that bacterium A. 3.2Sup (5) was capable of growth in the medium indicated. The biochemical analysis of these EPS shows that retain $120.0 \mathrm{mg}$ of proteins and $104.6 \mathrm{mg}$ of carbohydrates per gram of dry weight of cells.

\subsection{Sorption of $\mathrm{Fe}(\mathrm{II})$}

The sorption isotherms were determined in three tests, which lasted for $1 \mathrm{~h}$ and containing EPS (at a concentration of $0.83 \mathrm{mg} \mathrm{ml}^{-1}$ EPS) and an initial $\mathrm{Fe}(\mathrm{II})$ concentration of 200,1000 and $2000 \mathrm{mg} \mathrm{L}^{-1}$ (Fig. 1). The results of these experiments were EPS
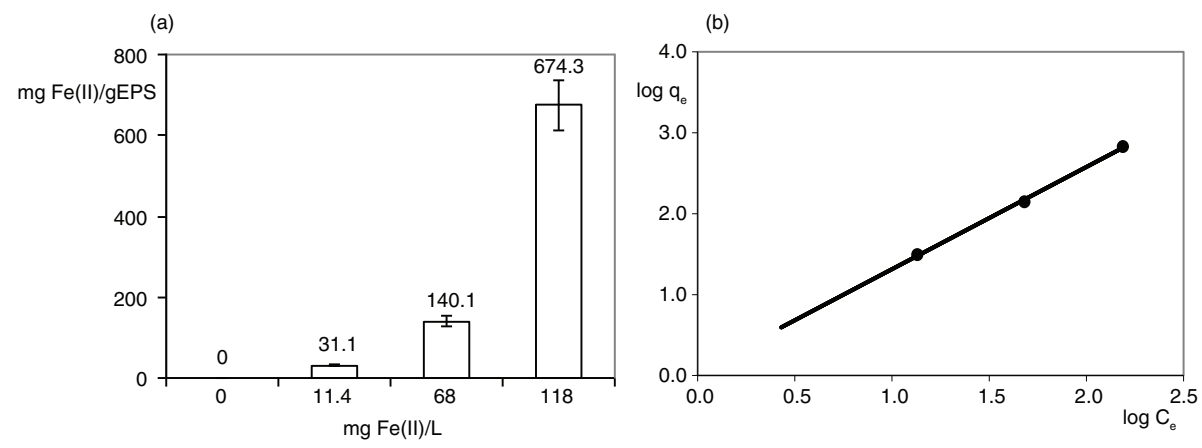

FIGURE 1. (a) Isotherm of Fe(II) uptake by pure EPS of A. 3.2Sup (5); (b) linearized Freundlich adsorption isotherm. 
adsorb $674.3 \pm 32.7 \mathrm{mg} \mathrm{Fe}(\mathrm{II})$ per gram of EPS at an initial concentration of $2.0 \mathrm{~g} \mathrm{~L}^{-1}$ of ferrous iron.

Besides, Fig. 1a shows EPS adsorbed iron exponentially to the equilibrium metal concentration that suggests that EPS were unable to reach saturation of their functional groups in the concentration range studied. This performance seems to indicate that the sorption of ferrous ion can be fitted to the Freundlich model, which adopts the following expression: $\mathrm{q}_{\mathrm{e}}=\mathrm{KC}_{\mathrm{e}}^{(1 / \mathrm{n})}$ where $q_{e}$ is the specific amount of metal adsorbed (mg Fe $\left.\mathrm{gEPS}^{-1}\right), C_{e}$ is the metal equilibrium concentration $\left(\mathrm{mg} \mathrm{Fe} \mathrm{L}^{-1}\right)$, and $K$ and $n$ are Freundlich constants. These parameters represent the sorption intake and intensity by the biosorbent, respectively, and can be calculated from the linear expression of the model.

The fitting of experimental data to the linear expression of such model (Fig. 1b) was corroborated by the good regression coefficient $\left(R^{2}=0.99\right)$. The parameters values obtained were: a metal sorption uptake of $K=1.14 \mathrm{mg}^{1-1 / \mathrm{n}} \mathrm{L}^{1 / \mathrm{n}} \mathrm{g}^{-1}$ with a sorption intensity of $1 / n=1.26$.

These values indicate that these substances have a relatively high capacity of biosorption of the ferrous cation from aqueous solution, compared to other values already published. For instance, at an initial concentration of $2.0 \mathrm{~g} \mathrm{~L}^{-1}$ de Fe(II), these EPS adsorbed about $650 \mathrm{mg} \cdot \mathrm{g}^{-1}$ of metal, while EPS of bacteria Paracoccus zeaxanthinifaciens adsorbed $385 \mathrm{mg}^{-1}$ of $\mathrm{Fe}(\mathrm{II})$ (Moppert et al., 2009), EPS of bacteria Bacillus subtilis adsorbed $123 \mathrm{mg} . \mathrm{g}^{-1}$ (McLean et al., 1992) and EPS of bacteria Aspergillus terreus sorbed $6.3 \mathrm{mg} \cdot \mathrm{g}^{-1}$ (Kareem et al., 2014).

\subsection{Characterization of EPS (pure and loaded with iron)}

Figure 2 shows SEM micrograph of pure EPS (Fig. 2a) and EPS loaded with Fe(II) (Fig. 2b). The results indicate that these substances have a geltype texture characteristic of an organic polymer structure.
Figure 3 shows corresponding EDX microanalysis for these substances. For pure EPS the EDX analysis showed the presence of $\mathrm{S}, \mathrm{O}, \mathrm{K}, \mathrm{Ca}, \mathrm{Na}$ and $\mathrm{P}$ (Fig. 3a), which were produced when the medium salts were used as growth source. For EPS loaded with iron, the microanalysis of these substances showed the presence of iron (Fig. 3b), in agreement with the results obtained in the sorption tests. Besides $\mathrm{C}$ and $\mathrm{O}$, sulphur was also detected. This element would come from the sulphate salt used as iron source.

\subsection{Characterization of the Active Sites in the Biosorption of $\mathrm{Fe}(\mathrm{II})$}

The EPS loaded with metal was characterized by using Fourier transform infrared (FTIR) spectroscopy and compared with EPS without Fe(II) (Fig. 4).

The infrared spectrum for pure EPS (Fig. 4a) is characterized by the presence of two main bands. At 1728 and $1401 \mathrm{~cm}^{-1}$, attributed to the asymmetric stretching vibration of the $\mathrm{C}=\mathrm{O}$ bond in the carboxyl, and to the deformation vibration of the $\mathrm{C}-\mathrm{O}$ bond in one of its derivatives (carboxylate), respectively (Omoike and Chorover, 2004). Moreover, the former band is also present in the IR spectrum of EPS loaded with Fe(II) (Fig. 4b), slightly shifted to the right, at $1626 \mathrm{~cm}^{-1}$, which would be an indicative of the participation of the carboxyl group in the interaction with the cation. Further evidences of this interaction are the transmittance values for the carboxyl and carboxylate groups: with a similar peak height in the spectrum of pure EPS (bands at 1728 and $1401 \mathrm{~cm}^{-1}$ ), respectively. However, with a lower intensity for the carboxyl than for the carboxylate group in the spectrum of EPS loaded with metal (bands at 1626 and $1401 \mathrm{~cm}^{-1}$ ), respectively. This suggests that the relative concentration of the carboxyl group decreased substantially after metal uptake which would support the participation of the carboxyl group in the interaction with $\mathrm{Fe}(\mathrm{II})$.
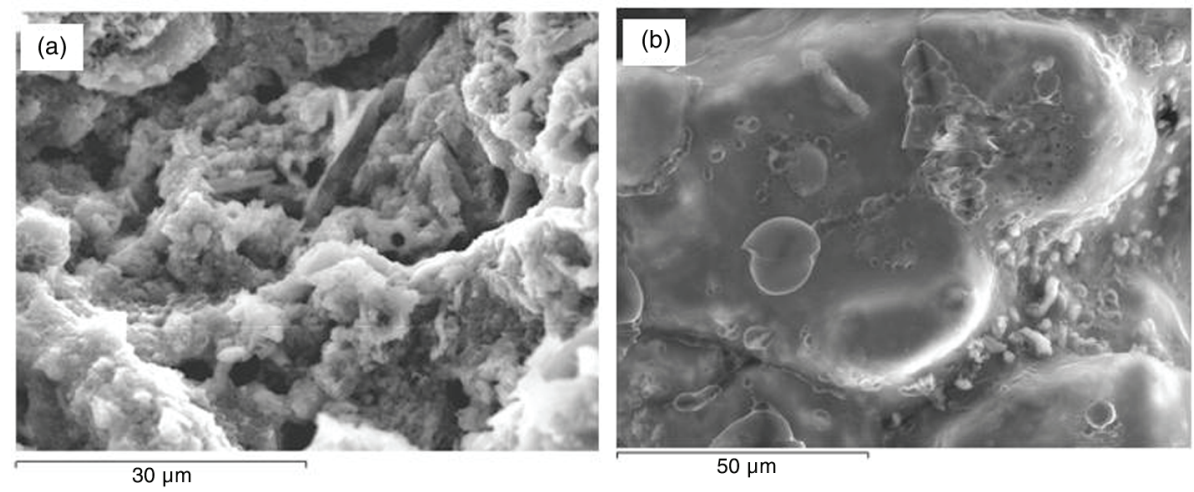

Figure 2. SEM micrograph of: (a) pure EPS of A. 3.2Sup (5); (b) EPS of $A .3 .2 \operatorname{Sup}(5)$ containing Fe(II). 

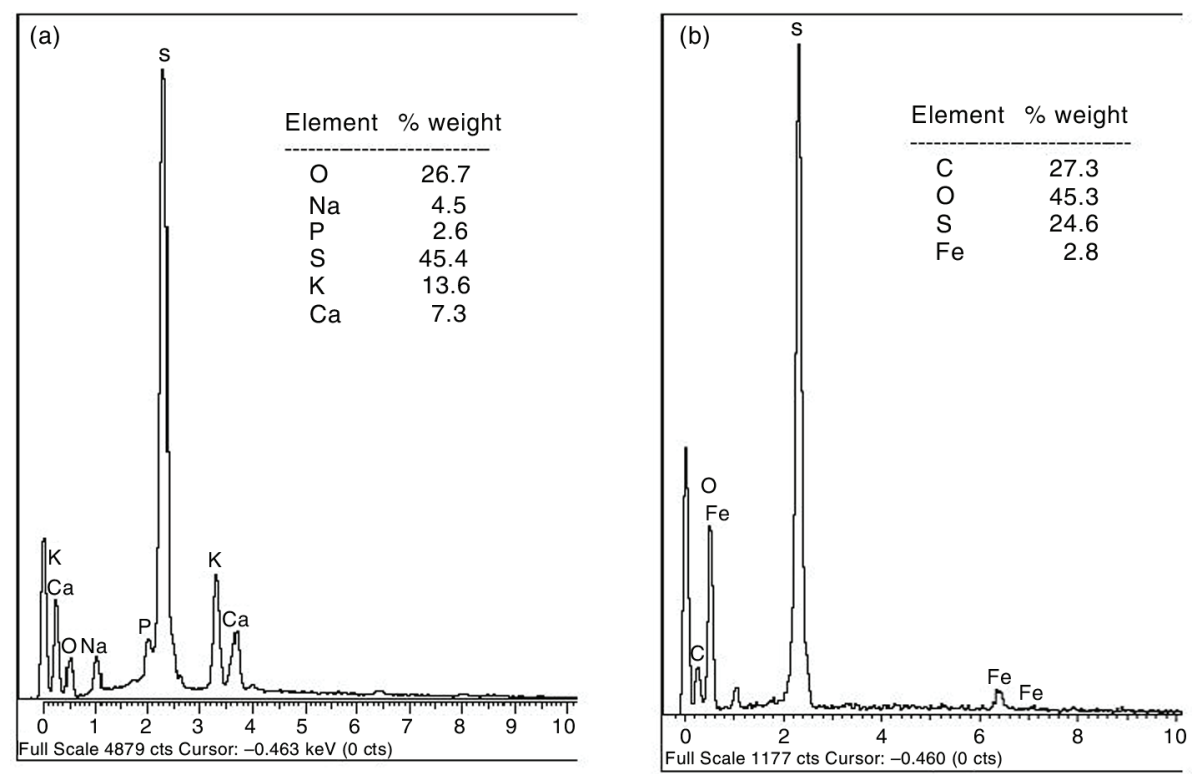

FIGURE 3. EDX spectrum of: (a) pure EPS of A. 3.2Sup (5); (b) EPS of A. 3.2Sup (5) containing Fe(II).

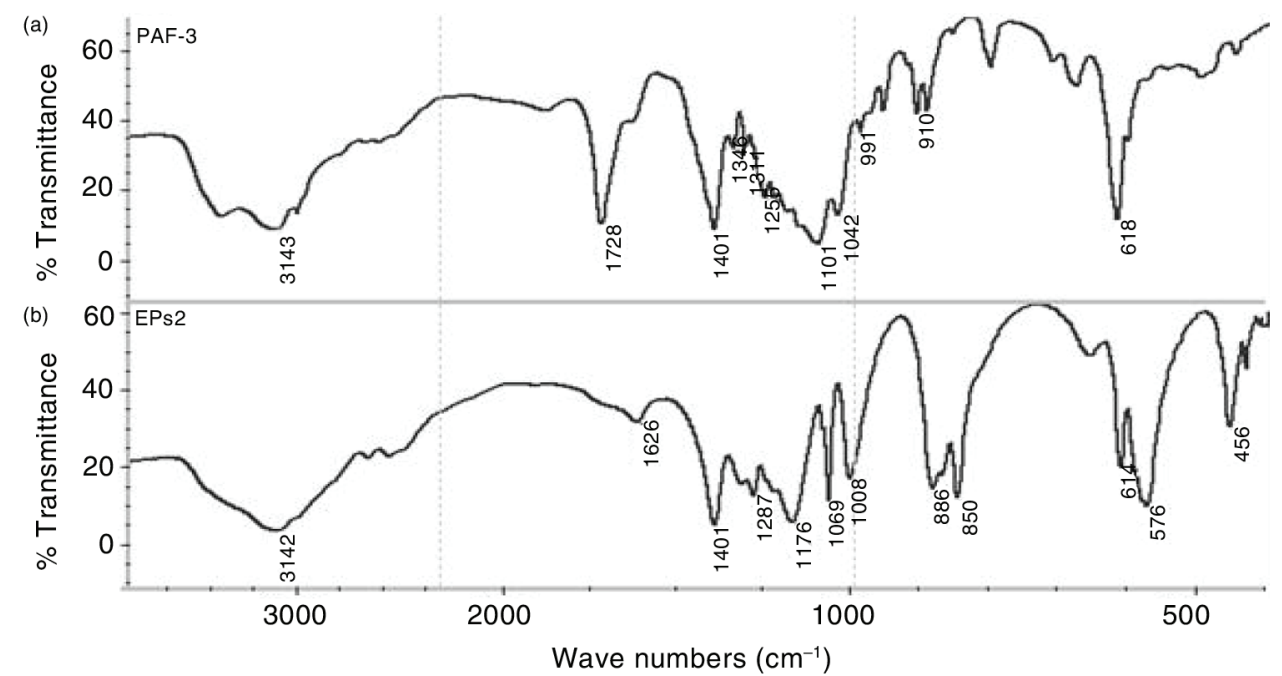

Figure 4. FT-IR spectra of: (a) pure EPS of $A$. 3.2Sup (5); (b) EPS of $A$. 3.2Sup(5) containing Fe(II).

On the other hand, in the spectrum of exosubstances loaded with metal (Fig. 4b) the two bands at 850 and $886 \mathrm{~cm}^{-1}$ may be attributed to the interaction of metal with the sulfonate group (Figueira et al., 1999). Finally, both spectra show a band around $3140 \mathrm{~cm}^{-1}$ commonly related whether to the stretching vibration of the $\mathrm{O}-\mathrm{H}$ group in polysaccharides, or to the presence of residual moist in the sample (Schmitt and Flemming, 1998).

Therefore, the EPS-Fe(II) interaction took place mainly through the carboxyl and sulfonate functional groups. Nevertheless, the interaction of the ferrous cation with these functional groups would also depend on the EPS composition. In a previous study, it was determined by titration that EPS of A. 3.2Sup (5) are mainly constituted by carboxyl groups (Tapia et al., 2011). Thus, this would be the main functional group interacting with the ferrous ion.

\subsection{Fe(II) Speciation in Acid Solutions}

Depending on the $\mathrm{pH}$ value, $\mathrm{Fe}(\mathrm{II})$ can act as a free cation or hydrolyzed as $\mathrm{FeOH}_{(\mathrm{aq})}^{+}$or $\mathrm{Fe}(\mathrm{OH})_{2(\mathrm{aq})}$. The latter species could in turn precipitate at circumneutral $\mathrm{pH}$ as $\mathrm{Fe}(\mathrm{OH})_{2(\mathrm{~s})}$. In addition, in sulphate medium, ferrous ion may form $\mathrm{FeSO}_{4(\mathrm{aq})}$ and complexes with the bisulphate anion such as $\mathrm{FeHSO}_{4(\mathrm{aq})}^{+}$ 
(Konhauser, 2007). Nevertheless, in dilute acidic solutions at room temperature, $\mathrm{Fe}$ (II) is mainly found as a free cation since hydrolysis (Morel and Hering, 1993) and bisulphate complexes (Casas et al., 2005) are not relevant processes. Consequently, it is reasonable that the uptake of this cation by EPS takes place through a direct interaction between their active groups and the free ferrous cation $\left(\mathrm{Fe}^{2+}\right)$.

\subsection{Sorption Mechanism of Fe(II) by EPS}

A raise of the acidity in the solution of EPS in contact with the ferrous cation was observed during all the sorption tests. These tests show that $\mathrm{pH}$ decreased from 2.47 to $2.38,2.32$ to 2.05 and 2.18 to 1.88 at 200,1000 and $2000 \mathrm{mg} \mathrm{L}^{-1}$ of initial ferrous concentration. According to this, the biomass released protons during the uptake of $\mathrm{Fe}(\mathrm{II})$ and proton exchange should be one of the main mechanism involved in the interaction. This mechanism has been referred to as one of the most important in the metal uptake by EPS (Guibaud et al., 2009).

The amount of protons released by the biomass increased almost linearly with the amount of $\mathrm{Fe}(\mathrm{II})$, with a slope value close to 2.0, which may represent the molar ratio between the amount of ferrous ion adsorbed by the biomass and protons release by it.

A possible source of the protons release in the process could be the carboxyl group, $\mathrm{RCOOH}$. The dissociation of this active group would be responsible for the rise in acidity, and the release of carboxylate anions, $\mathrm{RCOO}^{-}$, which could interact with ferrous ions. In this case, the interaction should involve two carboxylate groups per iron atom in agreement with the molar ratio (amount of protons release to ferrous ions adsorbed) determined previously.

In order to determine the type of interaction, the difference between bands corresponding to the stretching vibration of $(\mathrm{C}=\mathrm{O})$ and $(\mathrm{C}-\mathrm{O})$ bonds were considered in the corresponding IR spectra (Fig. 4). In this case, those bands appear at values of $1626 \mathrm{~cm}^{-1}$, for the symmetric stretching vibration of the $\mathrm{C}=\mathrm{O}$ bond in the carboxyl group, and at $1401 \mathrm{~cm}^{-1}$, for the asymmetric stretching vibration of the $\mathrm{C}-\mathrm{O}$ bond in the carboxylate group. The difference between both bands, $225 \mathrm{~cm}^{-1}$, is within the range considered as typical for the formation of bidentate chelates from carboxylates (Figueira et al., 1999; Fuks et al., 2006).

Based on this, a possible interaction mechanism between EPS of A. 3.2Sup (5) and Fe(II) ions could involve the capture of a ferrous cation by two carboxyl groups forming a bidentate chelate, according to the following reaction:

$$
2 \mathrm{RCOOH}+\mathrm{Fe}^{2+} \rightarrow 2 \mathrm{RCOO} * \mathrm{Fe}+2 \mathrm{H}^{+}
$$

The equilibrium constant for the reaction is given by the expression:

$$
\mathrm{K}=\frac{\left[\mathrm{H}^{+}\right]^{2}}{\left[\mathrm{Fe}^{2+}\right]}
$$

where, $\left[\mathrm{H}^{+}\right]$and $\left[\mathrm{Fe}^{2+}\right]$ are the concentration (in mol $\mathrm{L}^{-1}$ ) of protons release and ferrous iron adsorbed by the biomass, respectively.

The value of this constant can be calculated by substituting in Eq. (2) the values of concentrations for these cations reached in the interaction tests performed at the initial concentrations of 200, 1000 and $2000 \mathrm{mg} \mathrm{L}^{-1}$ of $\mathrm{Fe}(\mathrm{II})$.

The calculated values of $\log \mathrm{K}$ were $0.51,0.65$ and 1.14, respectively, with a average value of $\mathrm{Log}$ $\mathrm{K}$ of $0.77 \pm 0.33$, which indicates that the sorption of this cation proceeds reversibly. Thus, ferrous iron could be desorbed from exosubstances if it were necessary.

The interaction mechanism between EPS and $\mathrm{Fe}(\mathrm{II})$ proposed in reaction (1) suggests that the uptake of this cation would be associated to the formation of a dicarboxylate of $\mathrm{Fe}(\mathrm{II})$ with a linear structure such as that shown in Fig. 5.

For checking the previous proposal, the species contained in the EPS loaded with ferrous ion were determined by XRD analysis, which were compared with species contained in pure EPS. In EPS pure of $A$. 3.2Sup(5), Fig. 6a shows inorganic species such as mascagnite $\left(\left(\mathrm{NH}_{4}\right)_{2} \mathrm{SO}_{4}\right)$ and rapidcreekite

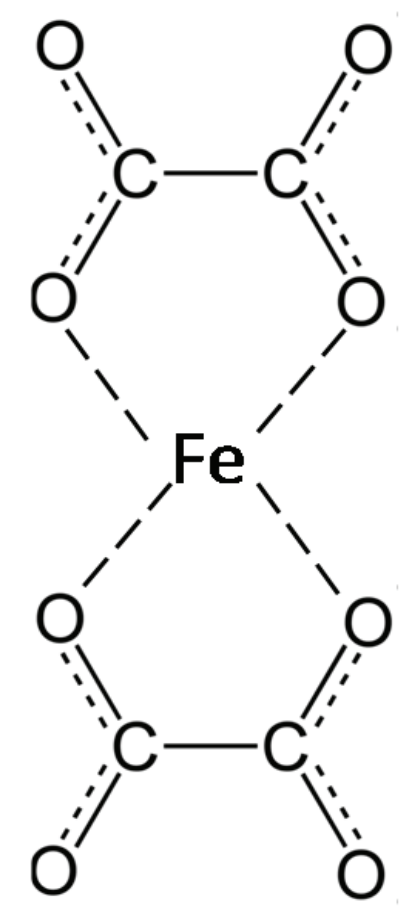

FIGURE 5. Structure proposal for bidentate chelate of Fe(II). 


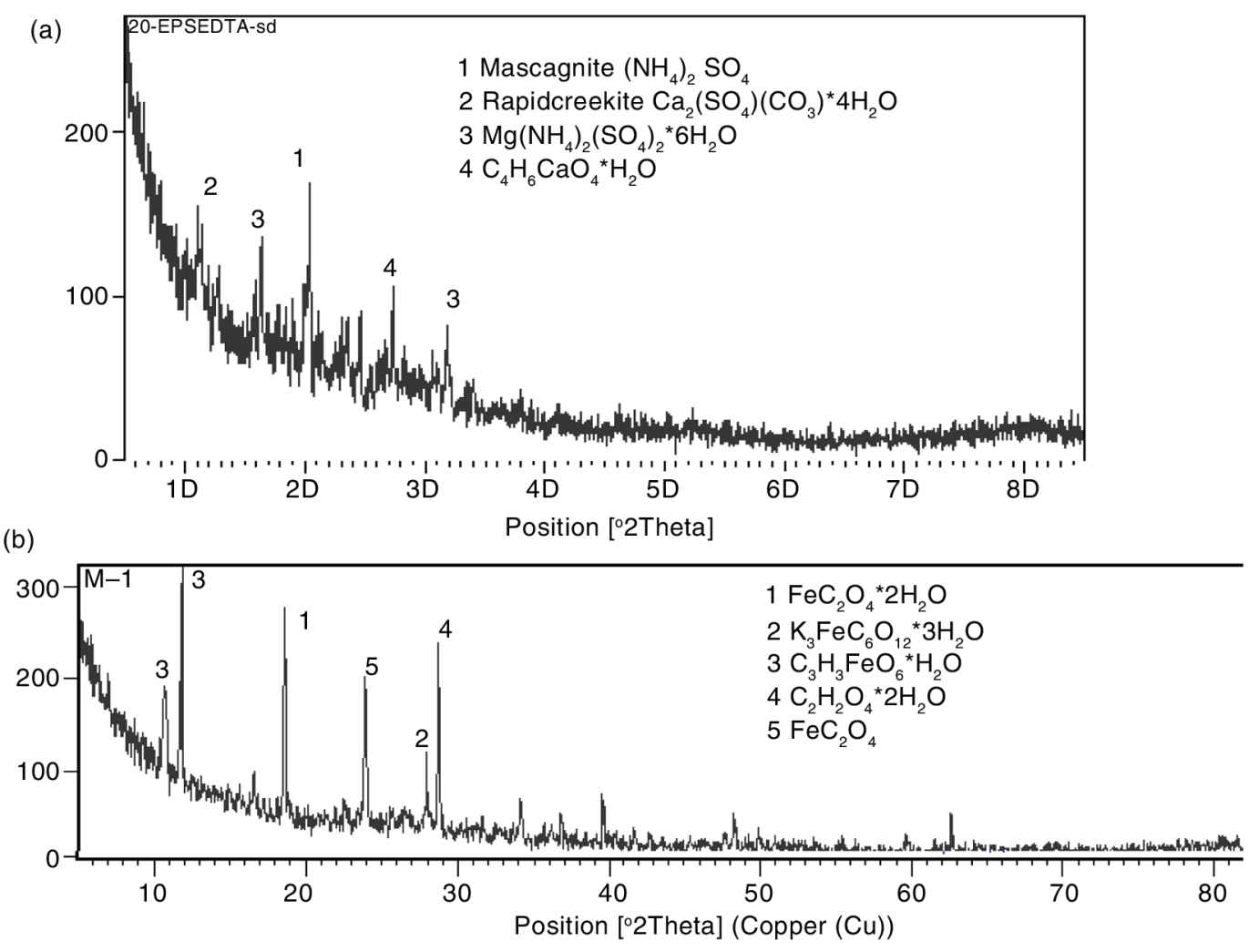

FIGURE 6. XRD Spectrum of: (a) pure EPS of A. 3.2Sup (5); (b) EPS of A. 3.2Sup (5) containing Fe(II).

$\left(\mathrm{Ca}_{2}\left(\mathrm{SO}_{4}\right)\left(\mathrm{CO}_{3}\right) * 4 \mathrm{H}_{2} \mathrm{O}\right)$, among others. In addition, the spectrum shows the presence of iron-free organic compounds $\left(\mathrm{C}_{4} \mathrm{H}_{6} \mathrm{CaO}_{4} * \mathrm{H}_{2} \mathrm{O}\right)$. These species were formed during the dehydration process associated to lyophilization of EPS solutions.

Meanwhile, the spectrum in Fig. 6b shows two ferrous oxalates: one anhydrous $\left(\mathrm{FeC}_{2} \mathrm{O}_{4}\right)$ and another dihydrate $\left(\mathrm{FeC}_{2} \mathrm{O}_{4} * 2 \mathrm{H}_{2} \mathrm{O}\right)$; which support the mechanism proposed in reaction (1). Besides the mentioned Fe(II) oxalates, the spectrum also shows the presence of other organic substances in lower proportion, such as: oxalic acid dihydrate $\left(\mathrm{C}_{2} \mathrm{H}_{2} \mathrm{O}_{4} * 2 \mathrm{H}_{2} \mathrm{O}\right)$, iron formate hydrate $\left(\mathrm{C}_{3} \mathrm{H}_{3} \mathrm{FeO}_{6} * \mathrm{H}_{2} \mathrm{O}\right)$ and minguzzite $\left(\mathrm{K}_{3} \mathrm{FeC}_{6} \mathrm{O}_{12} * 3 \mathrm{H}_{2} \mathrm{O}\right)$. In the latter compound, iron would be in the trivalent state indicating that the sample was partially oxidized during its handling. These results suggest then, the sorption of $\mathrm{Fe}(\mathrm{II})$ by EPS of A. 3.2Sup (5) takes place mainly through the formation of a bidentate oxalate of the mentioned ion, as proposed above.

\section{CONCLUSIONS}

The sorption of Fe(II) by EPS of Acidiphilium 3.2Sup (5) was fitted to the Freundlich model, with a metal sorption uptake of $K=1.14 \mathrm{mg}^{1-1 / \mathrm{n}} \mathrm{L}^{1 / \mathrm{n}} \mathrm{g}^{-1}$ and a sorption intensity of $1 / n=1.26$. The amount of ferrous iron adsorbed was $674 \pm 32.7 \mathrm{mg} F($ II) per gram of EPS at an initial concentration of $2.0 \mathrm{~g} \mathrm{~L}^{-1}$ of $\mathrm{Fe}(\mathrm{II})$. Ferrous ion sorption by EPS took place by preferential interaction with the carboxyl functional group $(\mathrm{RCOOH})$, which promoted the formation of ferrous oxalates $\left(\mathrm{FeC}_{2} \mathrm{O}_{4}\right)$, both hydrated and dehydrated. The reaction between EPS and $\mathrm{Fe}(\mathrm{II})$ is reversible ( $\log \mathrm{K}=0.76 \pm 0.13$ ). Therefore, the sorption of this ion can be reversed at convenience by applying the correct experimental procedure.

\section{ACKNOWLEDGMENTS}

This study was financially supported by the Research Training Program in Science and Technology of University Arturo Prat (Iquique, Chile).

\section{REFERENCES}

Casas, J.M., Crisóstomo, G., Cifuentes, L. (2005). Speciation of the $\mathrm{Fe}(\mathrm{Ii})-\mathrm{Fe}(\mathrm{Iii})-\mathrm{H}_{2} \mathrm{SO}_{4}-\mathrm{H}_{2} \mathrm{O}$ System at 25 and $50^{\circ} \mathrm{C}$. Hydrometallurgy 80 (4), 254-264. http://dx.doi.org/10.1016/j. hydromet.2005.07.012

Dopson, M., Ni, G., Sleutels, T. (2015). Possibilities for extremophilic microorganisms in microbial electrochemical systems. FEMS Microbiol. Rev. 40 (2), 164-181. http://dx.doi. org/10.1093/femsre/fuv044

Figueira, M.M., Volesky, B., Mathieu, H.J. (1999). Instrumental analysis study of iron species biosorption by sargassum 
biomass. Environ. Sci. Technol. 33 (11), 1840-1846. http:// dx.doi.org/10.1021/es981111p

Fuks, L., Filipiuk, D., Majdan, M. (2006). Transition metal complexes with alginate biosorbent. J. Mol. Struct. 792-793, 104-109. http://dx.doi.org/10.1016/j.molstruc.2005.12.053

Guibaud, G., Hullebusch, E.V., Bordas, F., d'Abzac, P., Joussein, E. (2009). Sorption of $\mathrm{Cd}(\mathrm{Ii})$ and $\mathrm{Pb}(\mathrm{Ii})$ by Exopolymeric Substances (Eps) Extracted from activated sludges and pure bacterial strains: Modelling of the Metal/Ligand ratio effect and role of the mineral fraction. Bioresource Technol. 100 (12), 2959-2968. http://dx.doi.org/10.1016/j. biortech.2009.01.040

Kareem, S., Adeogun, A., Omeike, S. (2014). Biosorption Studies for the Removal of Ferrous Ion from Aqueous Solution by Aspergillus Terreus and Trichoderma Viride: Kinetic, Thermodynamic and Isothermal Parameters. J. Water Supply Res Tech-Aqua 63 (1), 66-75. http://dx.doi.org/10.2166/ aqua.2013.109

Konhauser, K. (2007). Introduction to Geomicrobiology, Blackwell Publishing, Oxford.

Malki, M., González-Toril, E., Sanz, J.L., Gómez, F., Rodríguez, N., Amils, R. (2006). Importance of the iron cycle in biohydrometallurgy. Hydrometallurgy 83 (1-4), 223-228. http:// dx.doi.org/10.1016/j.hydromet.2006.03.053

Malki, M., De Lacey, A.L., Rodríguez, N., Amils, R., Fernandez, V.M. (2008). Preferential Use of an Anode as an Electron Acceptor by an Acidophilic Bacterium in the Presence of Oxygen. Appl. Environ. Microb. 74 (14), 4472-4476. http:// dx.doi.org/10.1128/aem.00209-08

Malki, M., Casado, S., López, M.F., Caillard, R., Palomares, F., Martín-Gago, J., Vaz-Domínguez, C., Cuesta, A., Amils, R., Fernández, V., Velez, M., De Lacey, A., Olea, D. (2013). Physicochemical Characterization of Acidiphilium Sp. Biofilms. Chem. Phys. Chem. 14 (6), 1237-1244. http:// dx.doi.org/10.1002/cphc. 201201034

McLean, R.J., Beauchemin, D., Beveridge, T.J. (1992). Influence of oxidation state on iron binding by Bacillus Licheniformis capsule. Appl. Environ. Microb. 58 (1), 405-408.
Moppert, X., Costaouec, T.L., Raguenes, G., Courtois, A., Simon-Colin, C., Crassous, P., Costa, B., Guezennec, J (2009). Investigations into the uptake of copper, iron and selenium by a highly sulphated bacterial exopolysaccharide isolated from microbial mats. J. Ind. Microbiol. Biot. 36 (4), 599-604. http://dx.doi.org/10.1007/s10295-009-0529-8

Morel, F.M.M., Hering, J.G. (1993). Principles and Applications of Aquatic Chemistry, John Wiley \& Sons, New York

Omoike, A. Chorover J. (2004). Spectroscopic Study of Extracellular Polymeric Substances from Bacillus Subtilis: Aqueous Chemistry and Adsorption Effects. Biomacromolecules 5 (4), 1219-1230. http://dx.doi.org/10.1021/bm034461z

Sand, W., Gehrke, T. (2006). Extracellular polymeric substances mediate bioleaching/biocorrosion via interfacial processes involving iron(III) ions and acidophilic bacteria. Res. Microbiol. 157 (1), 49-56. http://dx.doi.org/10.1016/j. resmic.2005.07.012

Schmitt, J., Flemming, H. (1998). Ftir-Spectroscopy in microbial and material analysis. Int. Biodeter. Biodegr. 41 (1), 1-11. http://dx.doi.org/10.1016/S0964-8305(98)80002-4

Tapia, J.M., Muñoz, J.A., González, F., Blázquez, M.L., Malki, M., Ballester, A. (2009). Extraction of extracellular polymeric substances from the acidophilic bacterium Acidiphilium 3.2sup (5). Water Sci. Technol. 59 (10), 1959-1967. http://dx.doi.org/10.2166/wst.2009.192

Tapia, J.M., Muñoz, J.A. González, F. Blázquez, M.L., Ballester, A. (2011). Mechanism of adsorption of ferric iron by extracellular polymeric substances (Eps) from a bacterium Acidiphilium Sp. Water Sci. Technol. 64 (8), 1716-1722. http:// dx.doi.org/10.2166/wst.2011.649

Tapia, J.M., Muñoz, J.A., González, F., Blázquez, M.L., Ballester, A. (2013). Sorption of Ferrous and Ferric Iron by Extracellular Polymeric Substances (Eps) from Acidophilic Bacteria. Prep. Biochem. Biotech. 43 (8), 815-827. http://dx.doi. org/10.1080/10826068.2013.805624

Wingender, J., Neu, T.R., Flemming, H.C. (1999). Microbial Extracellular Polymeric Substances. What Are Bacterial Extracellular Polymeric Substances?, Chapter 1, SpringerVerlag, Berlin, pp. 1-19. 